\title{
STRATEGY TO IMPROVE THE COMPETITIVENESS OF LOCAL NON-CARCASS CATTLE: A CASE STUDY AT CV MULTI JAYA MANDIRI BOGOR
}

\author{
Rosade Raqsi Fauzan*, Daryanto Arief, Jahroh Siti \\ School of Business, Bogor Agricultural University, Indonesia \\ ${ }^{*}$ E-mail: raqsi.fauzan@gmail.com
}

\begin{abstract}
The main objective of this study was to analyze the competitiveness of non-carcass cattle industry. The case study was conducted in a non-carcass management company in $\mathrm{CV}$ MJM. Initially an external scope analysis was conducted to identify problems that occurred in the company's marketing area in Jakarta, Bogor, Depok, Tangerang and its surroundings. The descriptive method used to identify non-carcass cattle commodities using the Porter's Diamond Model analysis, Internal Factor Evaluation (IFE) Matrix and External Evaluation Factors (EFE) are used to analyze internal and external factors in CV MJM, SWOT Matrix selected to create and determine the strategy to be applied and Analytic Network Process Analysis (ANP) used as a process to determine strategic priorities for the company. The results of SWOT Matrix in this research yield five alternative strategies chosen as strategy of increasing CV MJM competitiveness. The best strategy is taken based on expert decisions to improve corporate competitiveness that is maintaining customer satisfaction and loyalty.
\end{abstract}

\section{KEY WORDS}

Analysis, competitiveness, non-carcass, SWOT matrix.

Livestock is one of the agricultural sectors which grows rapidly every year. It is supported by the development of livestock products processing industries such as meat, derivative products, milk, eggs, and other processed products. Based on BPS data (2016), livestock and plantation are ones of the sub-sectors which contribute significantly to Indonesia's agricultural development, of which livestock is by $5.44 \%$ while plantation is by $5.83 \%$. Increased demand in the livestock sector has an impact on domestic stock needs. Beef production in Indonesia particularly is still very low. Therefore, the government's solution is importation in order to achieve national food prices stability. In addition to carcass or beef, people also consume beef offal which is a derivative product from cow, which is noncarcass. Generally, Indonesian people call it as jeroan (offal). Non-carcass is divided into several parts of the animals body slaughtered or is usually called as parts except muscles and bones. Non-carcass can be separated into three categories: fancy and variety meat which consist of tongue, lips, tail, and back meat, manufacturing meat or industrial meat consists of fatty meat, and edible offal which consists of liver, heart, kidney, tongue, intestine, brain and others. Non-carcass consumption has become a familiar thing in Indonesian society. It is also easy to find in soto seller, Padang restaurant, meatball, and others. According to Meat \& Livestock Australia (MLA) in 2017, exports to Indonesia were high for manufacturing meat and edible offal as much as $30 \%$ for meatball industry. According to the Livestock Service Office of West Java (2016), the largest cattle non-carcass consumption is in West Java and DKI Jakarta.

One of the companies involved in non-carcass providers in Bogor is CV Multi Jaya Mandiri (MJM). This company is engaged in the storage, distribution and marketing of beef offal. CV MJM cooperates with PT Elders Company which is located at campus of IPB Dramaga Bogor. PT Elders is a slaughterhouse company founded in 2006 in Indonesia which has a high standard in slaughterhouses. PT Elders based in Australia and was founded in 1839. The carcass and non-carcass produced by PT Elders are the best, but noncarcass is not the selling value of PT Elders. In addition to having ISO 9001 certification, PT Elders also has an ASAP GLOBAL standard which is in accordance with the standards of its home country. Non-carcasses from the slaughterhouse at RPH Elders are not absorbed by 
$\mathrm{RPH}$, but these non-carcasses are usually auctioned off to individuals or sellers. CV MJM establishes a full partner for all non-carcass products produced by RPH in the slaughter day. CV MJM has the authority to participate in selecting the products of RPH before it is packaged, stored and distributed to areas of Jakarta, Bogor, Depok, Tangerang and Bekasi (Jabodetabek) and its surroundings including Cianjur and Sukabumi. The main consumers of CV MJM are traditional markets in Jabodetabek (Jakarta, Bogor, Depok, Tangerang and Bekasi) and its surrounding, then companies such as PT Ajinomoto (Masako), PT Bahtera Internaniaga Internusa (Pronas), Wardah, and meatball factories.

Problems which occur in the scope of the external industry began when the noncarcass import quota was reopened of which the Indonesian government had legalized in mid 2016. The first import after the legalization reached 32,202,553 volumes/(kg) which in the previous year only reached $2,473,262$ volumes $/(\mathrm{kg})$. Its increase could be estimated at $1302 \%$. The import budget in 2016 in the beef offal sub-sector reached 75 million USD. It can be seen in Table 1 that the government budget for the import is quite large in the sub-sector of the beef products and beef offal. Table 1 is data released by veterinary public health (KESMAVET) in 2017.

Table 1 - Import Budget of Livestock Sub-sector in 2012-2016

\begin{tabular}{llllll}
\hline \multirow{2}{*}{ Imported Animal Product Sub-sector } & \multicolumn{5}{c}{ Value (USD) / Year } \\
\cline { 2 - 6 } & 2012 & 2013 & 2014 & 2015 & 2016 \\
\hline Cattle & 146.233 .711 & 222.222 .630 & 358.101 .409 & 237.157 .839 & 493.726 .376 \\
\hline Cattle (non-carcass) & 16.791 .528 & 27.380 .912 & 85.735 .575 & 14.081 .530 & 75.460 .274 \\
\hline Sheep/Goat & 8.083 .004 & 8.933 .812 & 10.831 .447 & 13.906 .748 & 10.878 .929 \\
\hline Non-cattle (non-carcass) & - & - & - & - & - \\
\hline Poultry & 1.545 .889 & 4.506 .847 & 4.729 .950 & 4.594 .523 & 6.192 .810 \\
\hline Other meat & 2.969 .714 & 906.308 & 1.064 .204 & 983.325 & 1.271 .495 \\
\hline
\end{tabular}

Source: Livestock and animal health statistic, 2017.

A large budget was issued by the government to import beef offal to restrainn the local prices to increase continuously in accordance with the increased financing of live beef cattle which affects the high prices of domestic beef and offal.

Then, in 2017, Indonesia officially established a partnership with the Indian state to import frozen buffalo meat and frozen buffalo offal which has been certified halal. It is actually considered problematic by Indonesia's standardization since India has not been free from Foot and Mouth Disease (FMD) in its beef cattle. The entry of hundreds of tons of smuggled frozen offal which are planned to be sold in bulk in various traditional markets in Indonesia will distort the domestic markets. The competition between the similar companies both local producers or frozen meat importing companies has triggered the increase of fierce competition. Based on the data from the Imported Animal Product Quarantine Installation (IKPHI) in 2016, there were 92 Limited Liability Companies (PT) and Commanditaire Vennootschap (CV) companies applied for offal import. As long as CV MJM runs its business, CV MJM also faces intense competition by domestic non-carcass competitors in the same industry, especially in the marketing area of CV MJM with its marketing target in traditional markets located in Jabodetabek (Jakarta, Bogor, Depok, Tangerang, and Bekasi) and its surrounding. Those competitors include PD Intan Jaya, CV Rian Jaya, CV Anugerah Perkasa, CV Sinar Offal, and CV Muti Jaya. When it is viewed from the Figure 1, the main competitor of CV MJM is CV Multi Jaya located in Jatinegara, East Jakarta which has the largest market share of $29 \%$. CV Multi Jaya cooperates with several RPHs in meeting their needs. It is in contrast to CV MJM which only cooperates with PT Elders. It could be strength for CV MJM, especially in the price offered by the suppliers because the suppliers give cheaper prices since CV MJM absorbs all non-carcass products from PT Elders. Tactics on price games, product quality, excellent service, and halal certification are used to improve the competitiveness of each company. 


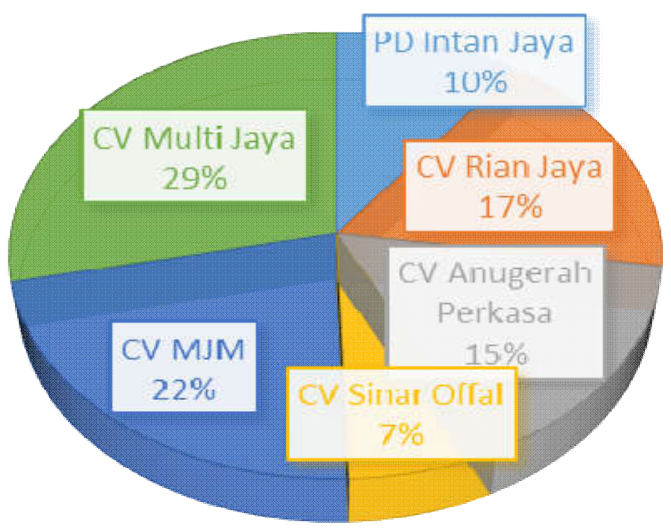

Figure 1 - Market share of local non-carcass industry in the marketing area of CV MJM

It certainly triggers the increase of fierce business competition. The existence of such competition makes industrial companies which manage cattle non-carcasses to get a bigger market share. Therefore, Porter's Diamond Model analysis is used in this research to determine the external environment which affects the local non-carcass industry. SWOT Analysis is required in order to analyze the internal and external conditions which occur in the current CV MJM and to formulate appropriate strategies in determining strategies to improve the development of local non-carcass cattle businesses in CV MJM.

\section{LITERATURE REVIEW}

Cattle Non-Carcass. It can be explained that, in addition to carcass, offal is halal and hygienic slaughtered animal bodies which consists of organs in the chest cavity and abdominal cavity, head, tail, legs starting from the tarsus/carpal bones down, udder, and reproductive organs. Offal is also often interpreted as a part of the livestock body other than carcass (offal) which has a lower economic value than carcass (Soeparno (2005) and Srigandono (1996)).

Competitive advantage (Porter's Diamond Model). Porter (1990) explains that condition factors refer to inputs used as production factors, such as labor, natural resources, capital and infrastructure. These variables are variables which already exist and are owned by an industry. The higher the quality of these input factors, the greater the industry opportunity to increase their competitiveness and productivity. Porter's Diamond Model consists of four determinants (determining factors) of competitiveness. These four attributes are the factors of conditions, demand conditions, related industries and supporting industries, as well as competition. The role of government and opportunities also plays an important role in determining the competitiveness.

SWOT Analysis. Wheelen and Hunger (2004) argue that SWOT analysis cannot only be used to identify the distinctive competence of a company, which is the capability of a certain expertise and the resources owned which strategically make a company different, but also can identify the company's inability in taking advantage of opportunities exist because of the limitations of certain sources. According to Rangkuti (2011), SWOT analysis is the systematic identification of various factors to formulate a company strategy. This analysis is based on logic which can maximize strengths and opportunities, but simultaneously can also minimize the weaknesses and threats. After knowing the strengths, weaknesses, opportunities, and threats, then the advantages of the opportunities that exist can be determined, as well as to minimize or even overcome the weaknesses they have in order to avoid the existing threats.

Analytic Network Process. The Analytic Network Process (ANP) method is a nonBayesian non-parametric qualitative approach for the decision-making process with a general framework without making assumptions (Ascarya 2006). Network spreads in all 
directions and allows the influence of a cluster on other clusters or the cluster itself and feedback which forms the cycle (Saaty in Nugroho 2008).

Conceptual Framework. In order to identify the company's strengths and weaknesses, an internal analysis of the company using the Internal Factor Evaluation (IFE) matrix was carried out. Meanwhile, for the opportunity and threat factors faced by the company, an external analysis using the External Factor Evaluation (EFE) matrix was carried out. Then, from the IFE and EFE matrix analysis, IE matrix which will map the current position of the company is obtained. The result obtained from the IE matrix is developed using a strategy with the Strenghts-Weakness-Opportunities-threats (SWOT) matrix. Based on the strategies formulated in the SWOT analysis, the most effective priority strategy was chosen by using ANP. The strategy implementation obtained from the analysis was then submitted to the CV MJM. The framework is summarized in the operational thinking chart in Figure 2.

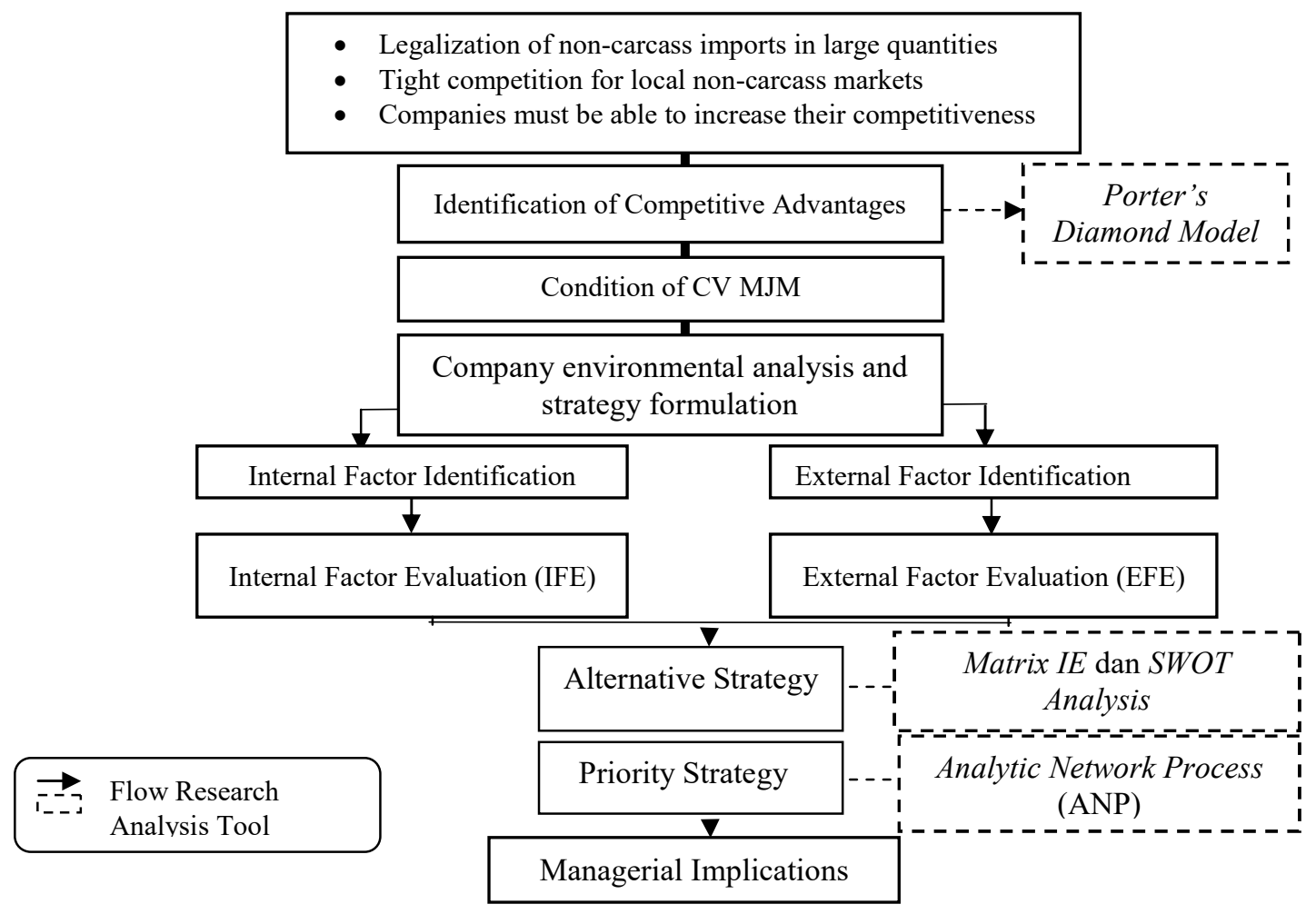

Figure 2 - Conceptual Framework of the Research

\section{METHODS OF RESEARCH}

The research location is at CV Multi Jaya Mandiri, Bogor District, West Java Province. The research has been conducted for three months, which is from January to April 2018. This research uses two types of data; those are primary data and secondary data. The primary data is obtained from in-depth interviews and filling out expert questionnaires by the internal parties, which are the owners of CV MJM and Production Heads. Meanwhile, the external parties are the Executive Director of NAMPA association, Director of KESMAVET for the 2006-2011 as well as an expert consultant for large ruminants, IPB's professor of livestock, and RPH PT Elders Manager/CV MJM distributor in order to determine the competitiveness factors and external-internal factors of the company, as well as for the formulation strategy. The secondary data is obtained from documents owned by the company and literature studies.

Data Analysis and Processing Method. The data processing and analysis of this research uses Porter's Diamond Model to identify the competitiveness of non-carcass cattle in the company's marketing area. In order to find out the strategies which can be done to 
improve the competitiveness of the company, SWOT Analysis method is used. According to David (2002), SWOT matrix (Strengths Weaknesses Opportunities Threats) is the right tool to assist managers in building four types of strategies, those are the SO (Strengths Opportunities) strategy, WO (Weakness Opportunities) strategy, ST (Strengths Threats) strategy and WT (Weakness Threats) strategy. Furthermore, the quantitative data from Porter's Diamond Model and SWOT Analysis are processed using software. Then, in order to compile and map out the strategies in improving the competitiveness of the company which has been obtained, Analytic Network Process (ANP) is used from the internal company party.

\section{RESULTS AND DISCUSSION}

Identification of Cattle Non-Carcass Competitiveness Factor. The competitiveness factors are analyzed based on competitive advantage theory of Diamond Porter's Model which consists of the factors of condition, demand condition, related industries and supporting industries, competition, company structure and strategy, as well as opportunities. Table 2 describes the assessment result of expert respondents in determining the external aspects of the local non-carcass cattle industry which occur at this time.

Table 2 - Factors that influence the competitiveness of the cattle non-carcass industry

\begin{tabular}{|c|c|c|c|c|c|c|}
\hline \multirow{2}{*}{ No } & \multirow{2}{*}{ Attribute } & \multicolumn{3}{|l|}{ Value } & \multirow{2}{*}{ Respondent } & \multirow{2}{*}{$\begin{array}{l}\text { Average } \\
\text { value }\end{array}$} \\
\hline & & 12 & 3 & 4 & & \\
\hline \multicolumn{7}{|c|}{ Condition Factor } \\
\hline 1 & Infrastructure resources & & 2 & 3 & 5 & 3,6 \\
\hline 2 & Quality human resources & & 3 & 2 & 5 & 3,4 \\
\hline 3 & Capital resources & & 3 & 2 & 5 & 3,4 \\
\hline 4 & Natural and environmental resources & 1 & 3 & 1 & 5 & 3 \\
\hline 5 & Science and technology resources & & 1 & 4 & 5 & 3,8 \\
\hline \multicolumn{7}{|c|}{ Demand Condition } \\
\hline 6 & The number of buyers and the growth rate buyers & & 2 & 3 & 5 & 3,6 \\
\hline 7 & Consumer preferences and tastes & 1 & 3 & 2 & 5 & 3,8 \\
\hline 8 & The intensity of non-carcass needs & 3 & 2 & & 5 & 2,4 \\
\hline \multicolumn{7}{|c|}{ Related Industries and Supporting Industries } \\
\hline 9 & Ability of domestic non-carcass suppliers & & & 5 & 5 & 4 \\
\hline 10 & The existence of hotel, restaurant and catering businesses & 1 & 4 & & 5 & 2,8 \\
\hline 11 & The existence of local traditional markets & & 1 & 4 & 5 & 3,8 \\
\hline \multicolumn{7}{|c|}{ Competition, Structure and Company } \\
\hline 12 & The level of competition in the local cattle non-carcass industry & 1 & 3 & 1 & 5 & 3 \\
\hline 13 & The presence of domestic competitors in the same industry & 1 & 4 & & 5 & 2,8 \\
\hline \multicolumn{7}{|c|}{ Role of Government } \\
\hline 14 & Encouraging the development of domestic non-carcass business & 1 & 4 & & 5 & 2,8 \\
\hline 15 & The role of government in shaping local demand conditions & & 1 & 4 & 5 & 3,8 \\
\hline \multicolumn{7}{|c|}{ Chance } \\
\hline 16 & Business climate & & 3 & 2 & 5 & 3,4 \\
\hline
\end{tabular}

The result is obtained based on the expert's assessment of the factors which affect the competitiveness development of the local non-carcass cattle industry. The first is the condition factor which are the aspect of science and technology resources (3.80), the second is the demand condition which is in aspect of consumer preferences and tastes (3.80), the third is the related industry and supporting industries factors in the aspect of the ability of domestic non-carcass suppliers (4.00) and the existence of local traditional market (3.80), while the fourth is the government factor in the aspect of forming local demand conditions (3.80).

Condition Factor (Resources of Science and Technology). Experts state that the progress of the recent food industry is supported by the advancement of science and technology. The company's ability to innovate by providing a different image of one product and another is supported by advanced technology.

Demand Condition (Consumer Preferences and Tastes). Experts assess that the consumers' preferences and tastes can represent the reasons for non-carcass (offal) 
products which are in great demand for most people in Indonesia. The current trend of Indonesian society is towards "Junk Food". According to statistics from the Directorate General of Animal Husbandry and Animal Health in 2016, the average consumption of products from farms has increased every year, which is meat from processed foods and preserved meats (sausages, nuggets, smoked meat, corned beef, etc.) of $29.06 \%$.

Related Industries and Supporting Industries (Ability of Domestic Non-carcass Suppliers and Existence of Traditional Markets). Experts state that the availability of raw materials is the most important compared to the others. The only place to get local noncarcass beef products is from the cattle slaughterhouses. Then, local traditional market is considered as the only place for the consumers to buy various kitchen needs, especially beef offal products.

Role of Government (The role of government in shaping local demand conditions). Experts state that the government has a role as regulator, facilitator, economic supervisor to advance industries in Indonesia, especially non-carcass industries. The steps taken by the government to keep the availability of domestic needs are by importing carcasses and noncarcasses of cattle from Australia, New Zealand and India, which was a large government policy in 2016.

Component Analysis of Porter Diamond Model Based on External SWOT (Opportunities and Threats). The second phase carried out in the formulation of strategies is to identify the strengths, weaknesses, opportunities and threats. This analysis is derived based on each component in Porter's Diamond Model analysis whose source of information comes from various literatures and interviews with the experts from KESMAVET government agency, meat processing and its derivative association (NAMPA), academics, and CV MJM company owners on the development of non-carcass industry cattle, especially in Jabodetabek. The result of the analysis can be seen in Table 3.

Table 3 - Porter Component Analysis's Diamond Model Based on SWOT External opportunities and threats

\begin{tabular}{|c|c|c|}
\hline Component & SWOT Identification & Factor \\
\hline \multicolumn{3}{|l|}{ Condition Factor } \\
\hline Resources of Science and Technology & Opportunities & $\begin{array}{l}\text { Management of local non-carcass cattle } \\
\text { in new medium-sized companies in the } \\
\text { temporary storage process }\end{array}$ \\
\hline \multicolumn{3}{|l|}{ Demand condition } \\
\hline \multirow[t]{2}{*}{ Consumer Preferences and Tastes } & Opportunities & $\begin{array}{l}\text { Indonesian people consider offal to be } \\
\text { part of a variety of culinary cultures }\end{array}$ \\
\hline & Opportunities & $\begin{array}{l}\text { Almost all non-carcass parts can be } \\
\text { processed and utilized by Indonesian } \\
\text { people }\end{array}$ \\
\hline \multicolumn{3}{|l|}{ Related Industries and Supporting Industries } \\
\hline \multirow[t]{3}{*}{ Ability of Domestic Non-carcass Suppliers } & Threats & $\begin{array}{l}\text { Supplier products have few substitute } \\
\text { items }\end{array}$ \\
\hline & Threats & $\begin{array}{l}\text { Local production has not been able to } \\
\text { meet domestic demand }\end{array}$ \\
\hline & Opportunities & $\begin{array}{l}\text { Advantages in terms of quality } \\
\text { possessed when compared with non- } \\
\text { carcass imports }\end{array}$ \\
\hline Existence of Traditional Markets & Opportunities & $\begin{array}{l}\text { The only consumer access to local cattle } \\
\text { non-carcass products }\end{array}$ \\
\hline \multicolumn{3}{|l|}{ Role of Government } \\
\hline $\begin{array}{l}\text { The role of government in shaping local } \\
\text { demand conditions }\end{array}$ & $\begin{array}{l}\text { Opportunities } \\
\text { Threats }\end{array}$ & $\begin{array}{l}\text { Ensure adequate domestic needs } \\
\text { The number of imported products } \\
\text { entering traditional markets can affect the } \\
\text { local market }\end{array}$ \\
\hline
\end{tabular}

Analysis of Internal and External Strategies Factor of CV MJM. In order to evaluate the internal factors, the Internal Factors Evaluation-IFE analysis method is used. In the IFE analysis method, each of these internal factors is given weight and rank. The weighting of each factor is obtained by pair-wise comparison technique. Meanwhile, in determining the 
weight of each factor, a scale of 1-5 is used based on the level of influence or strategic role of factors on the competitiveness of CV MJM. The result of the IFE analysis can be seen in Table 4.

Table 4 - Identify the strengths and weaknesses of MJM CV

\begin{tabular}{|c|c|c|c|c|}
\hline & Internal Strategic Factors & Weight & Rating & Score \\
\hline \multicolumn{5}{|c|}{ Strengths } \\
\hline 1 & Good company image and product & 0.11 & 4 & 0.44 \\
\hline 2 & Company access close to slaughterhouse & 0.10 & 4 & 0.40 \\
\hline 3 & Cooperation of all employees and a conducive working atmosphere & 0.09 & 4 & 0.36 \\
\hline 4 & International standard products & 0.10 & 3 & 0.30 \\
\hline 5 & Requests can be tailored to the wishes of consumers & 0.09 & 4 & 0.36 \\
\hline 6 & Provide product warranty & 0.08 & 4 & 0.32 \\
\hline \multicolumn{5}{|c|}{ Weaknesses } \\
\hline 7 & The unavailability of marketing personnel to acquire new customers & 0.13 & 1 & 0.13 \\
\hline 8 & Limited capital for business development & 0.09 & 1 & 0.09 \\
\hline 9 & Dependence on raw materials & 0.12 & 1 & 0.12 \\
\hline 10 & The product has no added value & 0.09 & 2 & 0.18 \\
\hline Tota & & 1.00 & & 2.70 \\
\hline
\end{tabular}

Based on the analysis of internal strategic factors, it can be seen that the main strength in improving the competitiveness of CV MJM is the good corporate image and product factors with a score (0.44). The internal strategic factor which falls into the category of the main weaknesses and influences is the unavailability of marketing personnel to get new customers (0.13). It affects the company performance due to the lack of more systematic and targeted marketing activities to maximize the product marketing. The result of the average value of the IFE Matrix shows that CV MJM is above the average with a value of 2.70 . It identifies that CV MJM Company is strong enough on its company's internal factors.

Analysis of the external environmental conditions of CV MJM includes the remote environment and industrial environment. The analysis produces several factors which become opportunities and threats. Opportunity and threat factors which can occur from outside the company are related to law, government and politics, economy, technology, customers, competitiveness and competition. External factors were analyzed using the External Factors Evaluation-EFE analysis method. The result of the EFE analysis can be seen in Table 5.

Table 5 - Identify the opportunities and threats of MJM CV

\begin{tabular}{|c|c|c|c|c|}
\hline No. & External Strategic Factors & Weight & Rating & Score \\
\hline \multicolumn{5}{|c|}{ Opportunities } \\
\hline 1 & Processed food consumption continues to rise & 0.13 & 4 & 0.52 \\
\hline 2 & The potential for non-carcass products to be the preferred processed food & 0.11 & 4 & 0.44 \\
\hline 3 & Part of Indonesian culture (culinary) & 0.10 & 3 & 0.30 \\
\hline 4 & High demand increase in Jabodetabek region & 0.11 & 3 & 0.33 \\
\hline \multicolumn{5}{|c|}{ Threats } \\
\hline 5 & Indonesian people prefer import non-carcasses because prices are much cheaper & 0.15 & 3 & 0.45 \\
\hline 6 & The emergence of competitors with large production capacity & 0.16 & 3 & 0.48 \\
\hline 7 & Business strategies are easy to imitate & 0.14 & 3 & 0.42 \\
\hline 8 & Health issues & 0.10 & 3 & 0.30 \\
\hline Tot & & 1.00 & & 3.24 \\
\hline
\end{tabular}

The main opportunity for CV MJM is the growing interest in the consumption of processed foods in packages with score of 0.52. The expert interview results stated that advanced product processing is needed by the company to provide additional value to the product. According to data from the Directorate General of Animal Husbandry and Animal Health in 2016, the average consumption of products from animal husbandry has increased every year; those are meat from processed foods and preserved meat (sausages, nuggets, smoked meat, corned beef, meatballs, etc.) for $29.06 \%$. The main threat to CV MJM is the emergence of competitors with large capacity $(0.48)$. Utilizing the potential by combining the 
resources and competencies of the CV MJM. The total score of external factors is (3.24) which mean that CV MJM already has good ability in its efforts to respond the external factors by taking advantage of opportunities and avoiding or facing threats/challenges.

SWOT Matrix. The result of the company's internal and external capability analysis in Figure 3 shows that the total IFE value is 2.70 and the total EFE value is 3.24 . CV MJM position in IE matrix is in quadrant II. The appropriate strategy for quadrant II is to grow and develop. The strategy emphasizes intensive strategies which is market penetration, market development and product development.

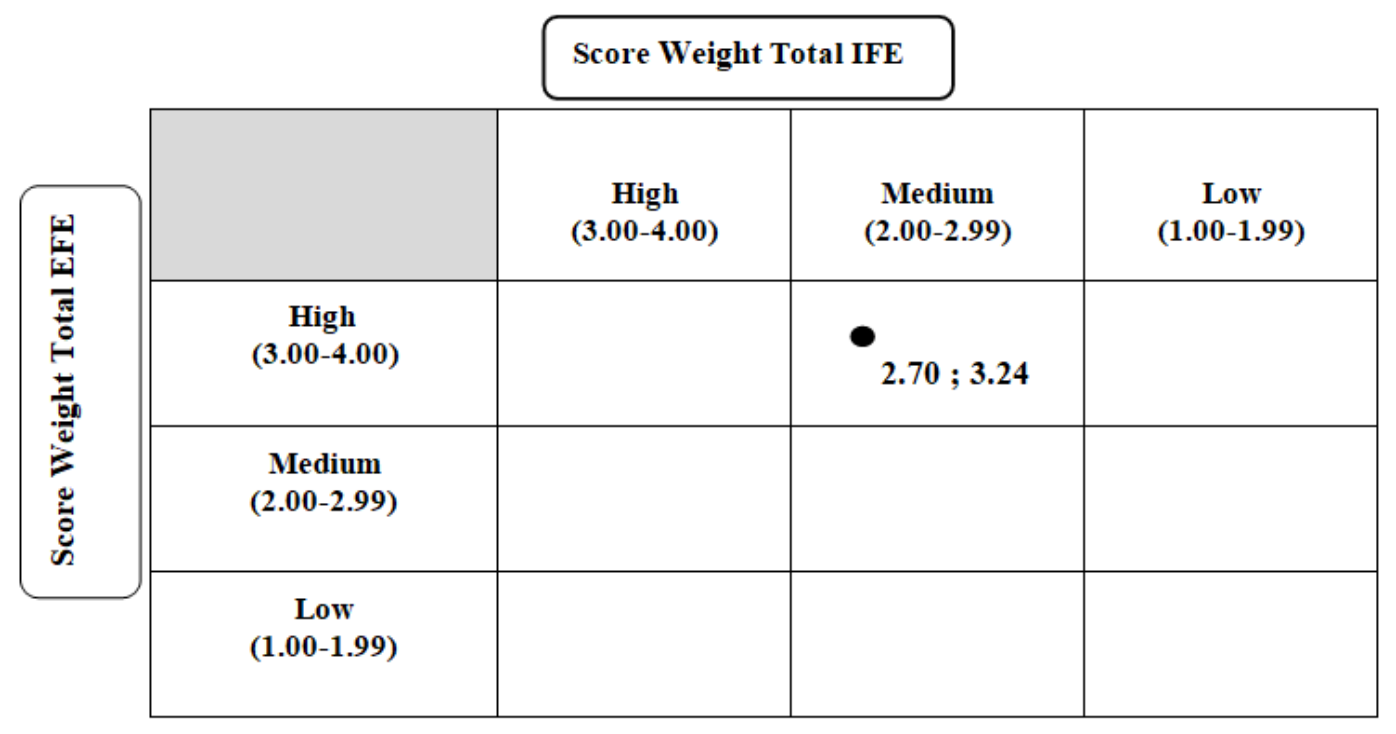

Figure 3 - IE Matrix CV MJM

Alternative strategies in improving the competitiveness of the CV MJM are carried out using a matrix analysis approach which is a continuation of the IFE and EFE Matrix analysis by matching the internal factors (strengths and weaknesses) occur in CV MJM company with the external factors (opportunities and threats) which are influential in the development of $\mathrm{CV}$ MJM's business. The SWOT matrix was used in formulating strategies to improve the competitiveness of CV MJM. By using SWOT Matrix, the strategy result consists of SO strategy (the use of power to take advantage of existing opportunities), WO strategy (utilizing opportunities to minimize the weaknesses), ST strategy (using force to overcome the existing threats) and WT strategy (minimizing weaknesses and avoid threats from the external environment). The following alternative strategies are generated in the SWOT matrix shown in Figure 4.

S-O Strategy (Strength-Opportunities). CV MJM can provide different services to get a market which has not been entered by the competitors. Doing a product development in accordance with the potential purchasing power of the community.

W-O Strategy (Weakness-Opportunities). At present, CV MJM does not have any official website in its business development plan yet, because CV MJM currently does not have any sales personnel. This can be an excellent opportunity for CV MJM to build a broader image and credibility without requiring more human resources.

Periodic business plan evaluation is expected to make the company more careful in making long-term business decisions. The goal is that the vision and mission of CV MJM can run well. Highlighting the quality side is a strategic step to differentiate the company's services and products. Good product quality can be a reference for the consumers to repurchase the product.

Leading to serving the market which has been owned by CV MJM. Strategic steps which should be done are not just focusing on finding new customers, but how CV MJM manages the existing customers by providing more optimal services to achieve customer satisfaction and loyalty. 


\begin{tabular}{|c|c|c|}
\hline INTERNAL & $\begin{array}{l}\text { STRENGTHS (S) } \\
\text { Good company image and product } \\
\text { company access close to slaughterhouse } \\
\text { Cooperation of all employees and a } \\
\text { conducive working atmosphere } \\
\text { International standard products } \\
\text { Requests can be tailored to the wishes of } \\
\text { consumers } \\
\text { Provide product warranty }\end{array}$ & $\begin{array}{l}\text { WEAKNESSES (W) } \\
\text { The unavailability of marketing } \\
\text { personnel to acquire new } \\
\text { customers } \\
\text { Limited capital for business } \\
\text { development } \\
\text { Dependence on raw materials } \\
\text { The product has no added value }\end{array}$ \\
\hline $\begin{array}{l}\text { OPPORTUNITIES (0) } \\
\text { Processed food consumption } \\
\text { continues to rise } \\
\text { The potential for non-carcass } \\
\text { products to be the preferred } \\
\text { processed food } \\
\text { Part of Indonesian culture } \\
\text { (culinary) } \\
\text { High demand increase in } \\
\text { Jabodetabek region }\end{array}$ & $\begin{array}{l}\text { Strategy S-O } \\
\text { Product development towards the niche } \\
\text { market (S1, S2, S3, S4, S5, S6, O1, O2, O3, } \\
\text { O4) }\end{array}$ & $\begin{array}{l}\text { Strategy W-O } \\
\text { Building business networking } \\
\text { through online media (W1, W2, } \\
\text { W3, W4, O1, O2, O3, O4) }\end{array}$ \\
\hline $\begin{array}{l}\text { THREATS (T) } \\
\text { Indonesian people prefer } \\
\text { import non-carcasses } \\
\text { because prices are much } \\
\text { cheaper } \\
\text { The emergence of competitors } \\
\text { with large production capacity } \\
\text { Business strategies are easy } \\
\text { to imitate } \\
\text { Health issues }\end{array}$ & $\begin{array}{l}\text { Strategy S-T } \\
\text { Evaluating business plans periodically by } \\
\text { involving the existing Human Resources (S1, } \\
\mathrm{S} 3, \mathrm{~S} 6, \mathrm{~T} 2, \mathrm{~T} 3 \text { ) } \\
\text { Full attention on the product quality control } \\
\text { from the process of sorting, packaging, } \\
\text { storing and distributing products to maintain } \\
\text { the quality ( } \mathrm{S} 1, \mathrm{~S} 2, \mathrm{~S} 3, \mathrm{~S} 4, \mathrm{~S} 5, \mathrm{~S} 6, \mathrm{~T} 1, \mathrm{~T} 4)\end{array}$ & $\begin{array}{l}\text { Strategy W-T } \\
\text { Giving a special treatment to the } \\
\text { consumers before and after } \\
\text { purchase (W2, W3, W4, T1, T2, } \\
\text { T3, T4) }\end{array}$ \\
\hline
\end{tabular}

Figure 4 - Alternative strategy

Selection of CV MJM Competitiveness Improvement Strategy. The indicators used to determine the priority of strategies to increase the competitiveness of CV MJM can be classified in 3 clusters, those are: factors, problems, and alternatives. Factor clusters explain the broad scope of the internal and external environment of the non-carcass business industry. The factor cluster consists of the resources of science and technology, the ability of domestic suppliers, the role of the government to shape the local demand conditions, the existence of traditional markets, as well as consumer preferences and tastes. Furthermore, the problem cluster is the internal and external constraints faced by CV MJM Company. Determination of weight was obtained using SWOT analysis method. The problem cluster consists of raw material dependence, the emergence of competitors with a large production capacity, Indonesian people preference of non-imported carcasses because of the low price, unavailability of sales personnel to get new customers, and business strategy which is easily replicated. Lastly, alternative cluster is an action in the form of a strategy which aims to improve the competitiveness of CV MJM. Alternative clusters consist of providing products according to the consumer demand, evaluating business plans regularly, maintaining product quality, as well as maintaining customer satisfaction and loyalty. The structure of the ANP model is shown in Figure 5.

Factor Cluster. Factor cluster result indicates that the attributes of consumer preferences and tastes towards non-carcasses are the most important attributes. Preference is formed from consumers' perceptions of the product. Experts assess that the preferences and tastes of consumers get the highest score in the clusters of factors which have an effect of $30.01 \%$. According to Kardes (2002), there are two preferences which are preferences based on attitudes and preferences on attributes. Consumer preference for non-carcass products belonging to CV MJM is attribute based preference. According to Kardes, attributebased preference is formed on the basis of comparing one or more attributes. This also applies to non-carcass products of CV MJM, some of the factors which affect it are good corporate image and many surrounding communities who are very familiar with the product and have relatively cheap prices at the price of competitors. 


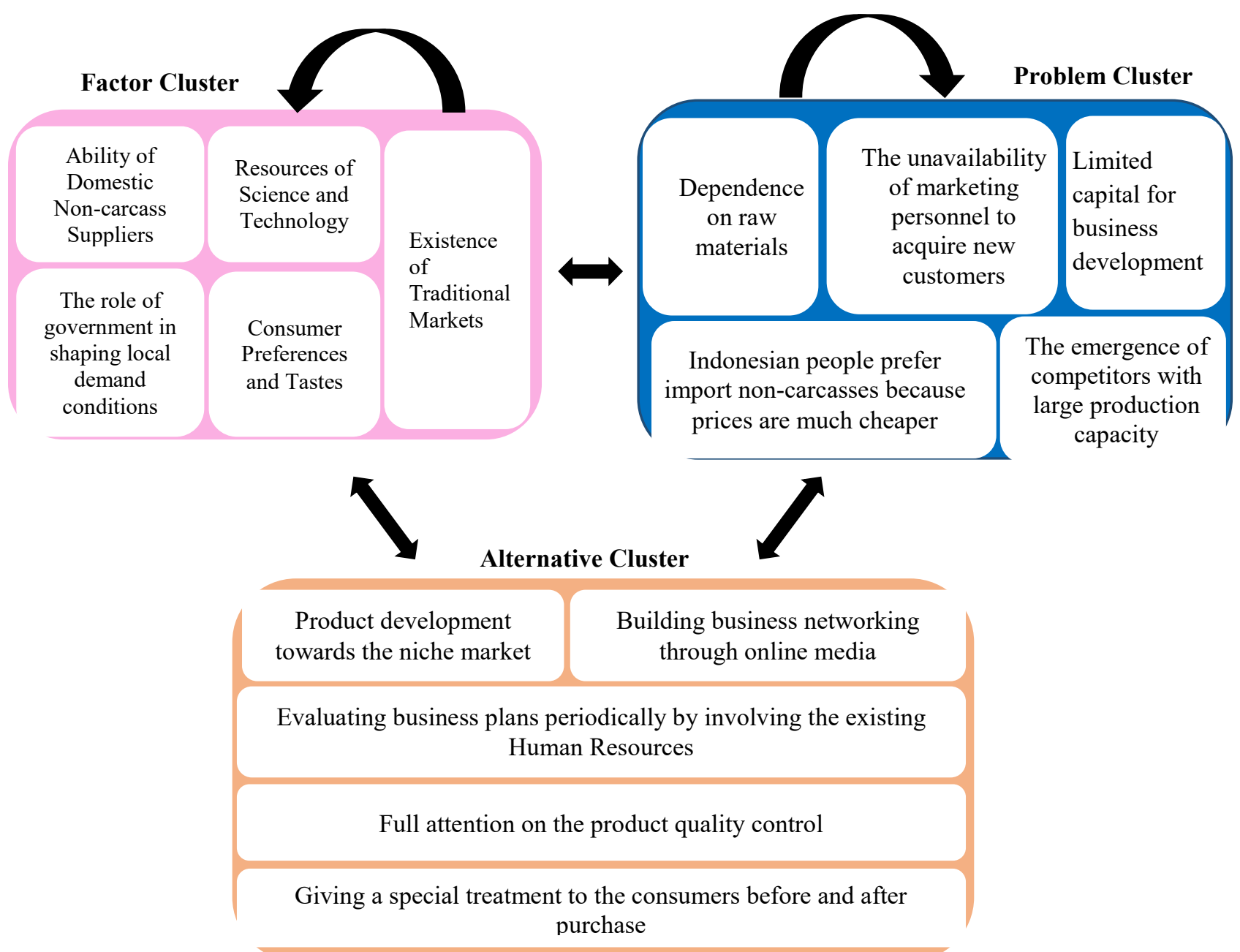

Figure 5 - ANP model structure

Resources of Science and Technology

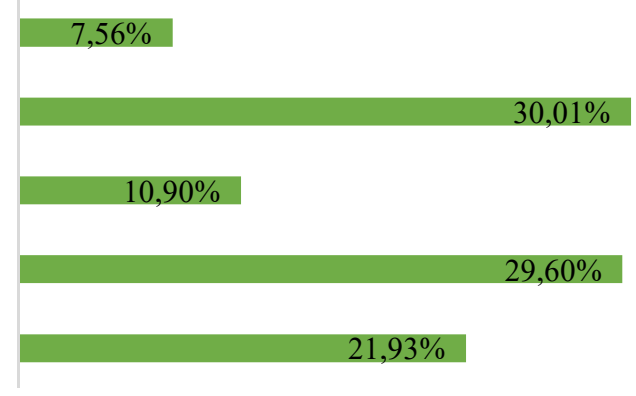

Consumer Preferences and Tastes

The role of government in shaping local demand conditions

Existence of Traditional Markets

Ability of Domestic Non-carcass Suppliers
$0,00 \%$
$10,00 \%$
$20,00 \%$
$30,00 \%$
$40,00 \%$

Figure 6 - Factor cluster priority

Problem Cluster. The main problem cluster comes from the external company. The analysis result shows that Indonesian people prefer non-imported carcasses because of the low price, with the biggest score of $26.63 \%$. This is consistent with the study conducted by Saleh (2011) who states that the shift of Makassar society to imported beef from many aspects of its research is on the aspect of low prices, while the excess of local beef in terms of quality and availability causes consumers to consume local beef. Sumarwan (2002) argues that prices are the product or service attribute which is mostly used by some Indonesian consumers who still have low income. Price is the main factor considered in choosing a product or service. Many traditional food businesses and processed meat industries such as sausages, burgers and meatball producers depend on the availability of 
beef and offal imports in the local market, because the price is cheaper than the local beef and local offal. It gives more benefits for their business. In general, the need for offal will continue to increase while local production tends to remain static, and the population growth continues to increase in West Java. In addition, some offal products are found to be illegal in traditional markets, causing the quality of the product is not be maintained.

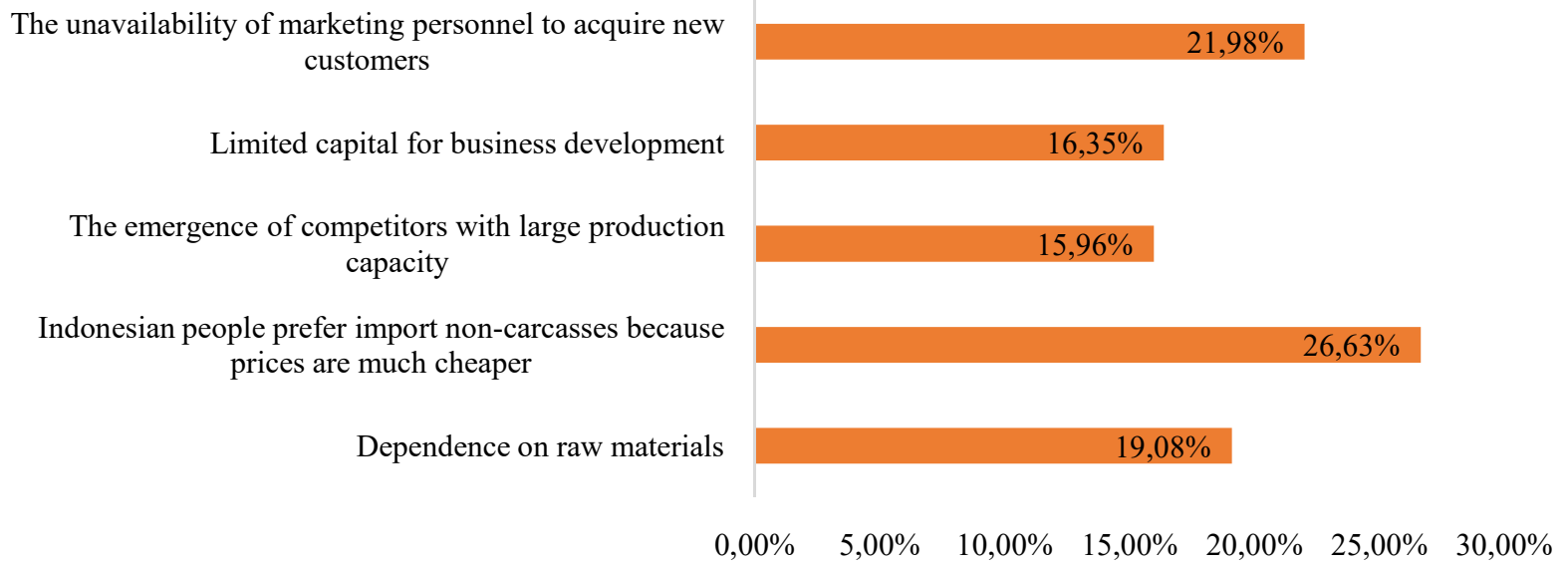

Figure 7 - Problem cluster priority

Alternative Cluster. The result in the alternative cluster indicates that the highest priority strategy alternative is to give special treatment to the consumers before and after purchase (27.35\%). Giving a special attention should be in terms of quality, quantity and service. This refers to Levit's book (1987) which states that the conditions which must be fulfilled by a company so that success in competition is trying to achieve the goal of creating and maintaining the customers. Hartono (2014) in his research explains that loyalty and willingness to conduct transactions continuously in the same company can occur if consumers are satisfied with the company's performance.

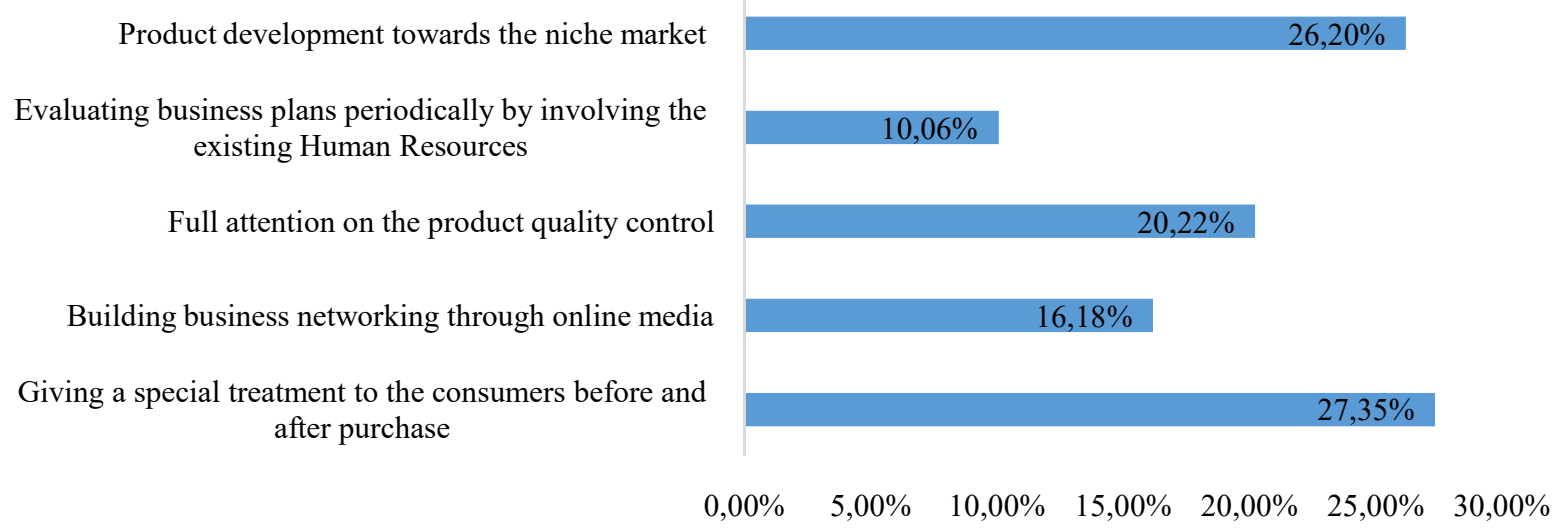

Figure 8 - Alternative cluster priority

\section{CONCLUSION}

The results showed that during this research, external strategic factors from the parameters of Porter's Diamond theory, namely the factors that affect non-carcass natural resources are conditions factors, demand factors, related industry and supported industry. The most important is the ability of domestic non-carcass suppliers (4.00), science and technology resources, consumer preferences and tastes, local traditional market, and also the role of government in create local demand condition (3.80). 
Based on the determination of SWOT on CV MJM, the main strength of the CV MJM is the company's image and good product. While the main weakness is due to the unavailability of marketing personnel to get new customers. The total score of (2.70) shows that the internal conditions of CV MJM are quite strong. The factor that becames main opportunity for CV MJM is a Processed food consumption continues to rise. Where as the main threat to CV MJM is there are The emergence of competitors with large production capacity. The total score of external factors is (3.24) which means that CV MJM already has the ability to respond to external factors by taking advantage of opportunities and avoiding or facing threats.

There are five alternative strategies generated from the SWOT Matrix which can be a reference for companies in increasing their competitiveness based on selected priorities from the ANP analysis of the company. The chosen strategy is giving special treatment to consumers before and after purchase.

\section{SUGGESTIONS}

It is necessary to increase the information system in the company to encourage more efficient marketing in the future and to be the differentiator between CV MJM and its competitors. A good company reputation can show the brand image to new companies who wants to be a partner with CV MJM.

Further research is needed that more in-depth and specific to any situation or condition. This further research can be focused on the field of marketing and logistics of local non-carcass products to provide information on effective and efficient types of marketing and distribution to support the company's strategy.

\section{REFERENCES}

1. Ascarya. 2006. Analytic Network Process: Pendekatan Baru dalam Penelitian Kualitatif. Bahan Lecture Series Metodologi Penelitian Pusat Pendidikan dan Studi Kebanksentralan. Jakarta: Bank Indonesia. Badan Pusat Statistik. 2014 Survei Sosial Ekonomi Nasional (SUSENAS) Tahun 2014, Jakarta: BPS.

2. [BPS] Badan Pusat Statistik. 2015. Pendapatan Nasional Indonesia 2011-2015, Badan Pusat Statistik Indonesia, Jakarta. [diakses pada tanggal 31 November 2017] Tersedia pada: https://www.bps.go.id/linkTableDinamis/view/id/914.

3. [MLA] Meat \& Livestock Australia 2017. Australian Livestock Export and Import Industry Statistical, Australia. [pada tanggal 31 November 2017] Tersedia pada: www.mla.com.au

4. Hartono F. 2017. Strategi kepuasan pelanggan dalam mempertahankan dan meningkatkan loyalitas pelanggan. Jurnal Ekonomi dan Akuntansi. 36;1-5.

5. Kardes, F. R. 2002. Consumer Behavior and Mangerial Decision Making Second. Edition. New Delhi (IND): Prentice Hall of India.

6. Levitt T. 1987. Imajinasi Pemasaran. Terjemahan. Jakarta (ID): Erlangga.

7. Peternakan Provinsi Jawa Barat. 2016. Laporan Tahunan Dinas Peternakan Provinsi Jawa Barat 2016. Provinsi Jawa Barat.

8. Porter, Michael E. 1990. The Competitive Advantage of Nations. The Macmillan Press.

9. Rangkuti, Freddy. 2004. Analisis SWOT, Teknis Membedah Kasus Bisnis. PT. Gramedia.

10. Saleh M, Ridwan M, Jafar. 2011. Analisis pergeseran permintaan konsumen jeroan sapi lokal dan impor di pasar tradisional kota makassar. Jurnal IImu dan Teknologi Peternakan. 3:213-217.

11. Soeparno. 2005. Ilmu dan Teknologi Daging. Gadjah Mada University Press. Yogyakarta.

12. Srigandono B. 1996. Beternak Itik pedaging. Gadjah mada Universitas Press, Yogyakarta. PT. Trubus Agriwidiya Unggara.

13. Sumarwan U. 2002. Perilaku Konsumen: Teori dan Penerapannya dalam Pemasaran. Bogor (ID): Ghalia Indonesia.

14. Hunger J D dan Wheelen T L. 2004. Strategic Management and Business Policy, Ninth Edition. New Jersey: Pearson Education, Inc. 